\title{
Mothers' employment and its consequences for investment in children ${ }^{1}$
}

Piotr Michoń

\section{Introduction}

The increasing labour market activity of women in the last three decades of the $20^{\text {th }}$ century triggered a public debate on potential consequences caused to a child by her/ his mother's absence from home. Nowadays, when the economic activity of mothers has become quite a common phenomenon, both across countries and social groups, the question of the consequences has returned. The increased interest in this subject is mainly due to a lively discussion on the question: What does it mean to be a good mother? The term "intensive mothering” was formulated by Sharon Hays (1996), and it is regularly addressed in media, and public and academic debate. Mothers' employment has become a bone of contention in the so-called mommy wars. Another reason to intensify discussions on the impact of mothers' employment on children's development is the implantation of social investment perspective in the debate on the direction of changes of the modern welfare state. Nowadays childhood is regarded as a period the consequences of which individuals will experience throughout their lives. The key experiences are those related to cognitive and non-cognitive development as they are of the utmost importance to individual's future welfare. In this context, everything that parents forsake when their children are young may have significant implications for the future of their offspring.

The paper focuses on child care as a way of investing in children. It does not address issues related to financial investments. The aim of the paper is to use the available empirical studies in order to analyse mothers' employment consequences

1 The paper was drafted under implementation of a research project "Welfare State and inequalities in subjective well-being - comparative studies of European countries", financed with funds of the National Science Centre (No. 2013/11/B/HS5/03618). 
for their children's development. Relying on the literature, I aspire to answer the following question: Does mothers' employment have negative consequences for children's development?

\section{Intensive mothering}

The term "intensive mothering" was formulated by Sharon Hays (1996) to describe the belief that good mothers should first and foremost be caregivers intensively raising their children. According to intensive mothering ideology, mothers are expected to invest vast amounts of energy, time, money and emotional labour for the good of their children (Elliott et al. 2015). Intensive motherhood consists of three elements. Firstly mothers are required to be the main and the most important carer for their children. It is based on an assumption that the child needs constant care provided by the primary caregiver and the mother is the person for whom this role is best suited. However, if for some reason the mother is unable to fulfil the role assigned to her, she may be replaced by another woman. Secondly, intensive motherhood requires mothers to devote their time and energy for the good of their children. As a result, the mother's life is to become subordinated to the welfare of the child. Child care absorbs emotionally, requires significant expenditures of time and energy, commitment and substantial preparation. Thirdly, and most importantly in the context of this paper, it is assumed that the intense mothering implies that the mother should resign from her professional career. She has to care for children, who deserve to be in the centre of her attention, and should treat them with absolute devotion. Under this approach woman is expected to be an ideal mother. She has to adapt her life to be caring and fully committed to her children. A woman with a child is primarily perceived as a mother, and when she works, the role of employee is only an addition to her identity. As women are employed not always by choice, intense motherhood is presented to them as an ideal to which they should aspire.

\section{Social investments}

The last decade of the $20^{\text {th }}$ century marked the beginning of a debate about why and how parental behaviours contribute to children's welfare. Economy based on knowledge and services required a change in the approach which had developed in the initial years after World War II. It was indicated that the main goal of social investments was to prevent the intergenerational transmission of poverty and to prepare new generations of employees to the requirements of the changing labour 
market. The market where the need for knowledge and skills would be increasingly high, job security would decrease, and the new non-standard forms of employment would develop and widespread. Social investments also aimed to make individuals responsible for their welfare as well as welfare of their families, and thus relieve the social security systems. The latter has become particularly important in terms of progressive aging of the population in rich countries. All these aspects emphasised the importance of investments in children and development of human capital. As Esping-Andersen wrote in 2002: A concerted child-focus is (...) sine qua non for a sustainable, efficient, and competitive knowledge based production system. The coming working-age cohorts will be small, and they must sustain huge retirement populations. The income security of pensioners two or three decades down the line will in large measure depend on how much we can mobilize the productive potential of those who today are children. More generally, the only real asset that most advanced nations hold is the quality and skills of their people (Esping-Andersen 2002: 28). Social investment, as a new paradigm of the welfare state, makes focusing our attention on childhood as a period of accumulation of skills and capacity development necessary for success in adulthood. In their calculations for Sweden, Klevermarken and Stafford (1999; based on: Hallberg, Klevmarken 2003: 207) estimated that the total investment in children had the same potency on economic growth as the total investment in machinery and buildings. Nowadays children are expected to be productive in the future, therefore it is necessary to use childhood for the purpose of the future. While this approach may give rise to concern (Michon 2014a) there is no doubt that the discussion on social investments revived a discussion on the relationship between working mothers and development of their children.

Investments in children are sometimes defined very broadly as "economic, cultural, social and interactive resources that parents provide for their children" (Hamilton et al. 2007). Researchers capture the concept of parental investment in different ways, however most of them agree that the resources and parenting practices are crucial for educational and professional achievements of the child. With an increase in the female labour force there were concerns that their employment will significantly reduce the time spent on child care. In other words, using modern terminology, it will decrease the level of parental investment in the child. It is easy to list arguments for this way of thinking. Activities such as paid work and child care usually are mutually exclusive. The time devoted to one of them cannot be dedicated to the other. In the case of the working mother, we must accept the fact that her ability to perform direct child care will be significantly reduced. In addition, according to the theory of opportunity costs, time devoted to caring reduces the time spent on making money, thus it is simply expensive. It is true especially for well-educated individuals with opportunities to find well-paid work. Next to time, energy is another resource that is used in the labour market. In the literature on work-life balance (Michon 2014b) a conflict of fatigue is indicated: a person who is very active on the labour market may be simply too tired to actively care for her children. 
The ideas of intensive mothering and parental investments are regularly subject to empirical verification. This paper presents an overview of the empirical findings. It also aims to answer the question: does mothers' employment harm children's development (as it is suggested by the intensive mothering approach)? The main assumption of intensive mothering ideology according to which mother is the parent that is primarily responsible for child care (as a form of investment in child) is investigated in this paper.

\section{Working mothers bad for children?}

Studies carried out mainly in the USA, Australia and the U.K. partly support the conclusion that mothers' employment can be detrimental to the development of their offspring. Children of mothers who are employed have been found to perform worse in tests in the field of cognitive abilities (Bernal 2008; Baum II 2003; Brooks-Gunn et al. 2002; Gregg et al. 2005; Hill et al. 2005). The fact that many mothers are active on the labour market and it is not always a matter of their choice may raise concerns about the quality of future generations. On the other hand, other studies show that employment of mothers during early childhood of their children has no impact on the children's behaviour in adolescence. Aughinbaugh and Gittleman (2004) indicated that there was no connection between risk behaviours, such as smoking, drinking alcohol, using marijuana and other drugs, sex and crime, observed in adolescents, and employment of their mothers when they had been very young (aged under 3 years).

Mothers' employment might be harmful to development of their children. However, relevant studies show that negative effects of the mothers' work occur only if their children are very young. The negative effect of lower results in tests of cognitive skills was identified but only in the cases where mothers had returned to work soon after birth. Baum II (2003) suggested that detrimental effect occurred if the mother went back to work before her child's first birthday. Similar results were presented by other authors (Brooks-Gunn et al. 2002; Hill et al. 2005). Ruhm (2004) extended that period to three years and stressed a minor negative impact of the mothers' employment on verbal abilities, reading and math achievements. However it must be added that the negative effect of mother's employment to child development reveals itself mainly when mothers work full-time (over 30 hours per week) (Brooks-Gunn et al. 2002; Hill et al. 2005; Bernal 2008; Gregg et al. 2005). For part-time workers no relationship of this type has been observed. Additionally, the negative effect of mothers' work has been mainly observed in the case of the besteducated mothers, and children who have the largest potential of growth (e.g. Gregg et al. 2005). The observation gains on importance where best educated mothers are most likely to return to employment relatively sooner than their less-educated 
counterparts. While most studies tend to indicate the positive role of parents' education for the child's cognitive development (e.g. Campaña et al. 2016) they do not take into consideration the fact that well-educated mothers are more likely to return to employment than the low-educated. In this case the problem seems to be caused by an insufficient use of high potential rather than arising difficulties. In the case of children belonging to disadvantaged groups, employment of their mothers (parttime employment in particular) has led to positive implications for the development of children (Ruhm 2008). Zaslow and Emig (1997) carried out a review of research on the impact of taking up employment by mothers to their children in poor families. The main conclusion was that the children rarely experienced any negative effects of employment of their mothers; more often positive effects, in the area of cognitive development in particular, were observed.

The literature suggests that mothers' employment leads to negative consequences (in the form of underused potential) to children of mothers with a high level of education, while no such consequences have been observed in children of mothers with a low level of education. Low level of maternal education is often associated with a poor material status. Mothers' paid work significantly increases welfare of their families which to some extent compensates for the loss resulting from their absence. A similar explanation is related to the stability of marriage. In the countries surveyed, less educated women are more likely to get divorced and become single parents. As a result the income earned by the mother compensates for possible losses (Brooks-Gunn et al. 2002). Additionally, women's income from work reduces stress levels resulting from family difficulties to make the ends meet (Khanam, Nghiem 2016). Another possible explanation is that child care provided by an educated parent may bring more benefits to the cognitive development of a child than care provided by a low-educated one. Bonke and Esping-Andersen (2011) suggest that the positive effect of parental education on children's cognitive development has its origins in a relatively greater amount of time spent on care, less traditional forms of care exercised by both parents (and not just the mother), more intense care and more equally shared between the parents. The higher the parents' education, the more time spent on educational child care (Campaña et al. 2016). Guryan and colleagues (2008) pointed out that in the United States, better educated parents spend more time with their children than people without higher education. It is partly surprising, since better educated people also spend relatively more time doing professional work (Guryan et al. 2008). Better educated parents spend more time caring for their children also in various groups: unemployed women, employed women and employed men. It is suggested that highly educated parents spend (actively) more time with their children while they are more aware of the link between time devoted to child care and the level of investments, they are also less likely to accept substitutes for parental time, and they are highly motivated to conform the norms of involved parenting (Sayer et al. 2004).

The idea of limited substitution of parental care and its impact on children's development can be perceived from the perspective of efficiency of non-parental 
care. The merits of intensive mothering would be relatively lower if non-parental care brings the same or similar effects on children as care provided by parents. A recent longitudinal study conducted in Australia involved a sample of more than 5,000 children and showed that children aged $4-5$ years who had never experienced the non-parental child care had lower vocabulary scores than those who had been covered by the non-parental care from birth through the age 3 (Lee 2016). The author of the study stresses, however, that non-parental child care has positively influenced the results achieved by children due to regulatory standards which result in quality control. Children who do not participate in organised forms of nonparental care were exposed to more risk factors (Lee 2016). Maternal characteristics primarily contribute to this association. Women who were looking after their children at home were more likely to have lower education, be unemployed single parents with lower income. Children who are subject to more risk factors (poverty, low maternal education, poor parental health or single parents) benefit more from receiving non-parental care. Numerous studies show that using external child care arrangements has positive effect on children's cognitive, language and motor skills, behaviour, school attendance, college advancement, attitudes towards education, and future wages (for review see: Brilli et al. 2013).

It is necessary to mention some significant limitations of some of the studies used. When analysing the impact of mothers' employment on their children's development, most authors assume homogeneity of child care. In other words, it is assumed that the following factors impact child' development: presence / absence of the mother, and the way how the child is cared for when the mother is at work. However it seems that this approach is only partly relevant. Studies conducted in the UK showed that the majority of children under 18 months of age were cared for by friends or relatives of their parents. Authors of the study stated that care exercised by persons without proper qualifications contributed to the slowdown of cognitive development of the children (Gregg et al. 2005). Quality of care and the home environment may be the factors mitigating the negative impact of mother's employment (Brooks-Gunn et al. 2002). Another important limitation of the research is application of tests which check children's cognitive abilities. Many authors find them controversial and their credibility is regularly criticised (Currie 2005). One should also be careful in terms of generalization of results as the effect of employment of mothers on their children's development may be different depending on the child and his or her family variables.

\section{The role of fathers}

According to the traditional family model woman is responsible for caring and housework while the man's role is to earn money to ensure the material welfare of the family. Thus as mother becomes employed her child "loses" his/her most important 
carer. It is worth noting that this reasoning is based on two assumptions: other carers do not have equally good effect on the child as does the mother; and no one is able to substitute mother in the process of investing in her children. A brief overview of research on the involvement of fathers in child care questions both these assumptions. It is shown that the care exercised by the father is extremely important for the development of the child, and at the same time, fathers increasingly play the role of carers, which is of significance.

The role of the father in the child's upbringing has already been recognised by researchers (see an overview Allen, Daly 2007; Lamb (eds.) 2010). Although I do not intend to make a comprehensive review of research in this subject, I would like to refer to the role fathers' care might play in investing in children. In various ways: by stimulating activity, physical care, showing parental warmth, and other activities related to taking care of the child; fathers reduce the risk of delays in the child's cognitive development (Bronte-Tinkew, Carrano, Horowitz, Kinukawa 2008; Lamb, Lewis 2010). Children of fathers who often interact with them, as early as 6 months of age, are at a relatively higher level of cognitive development (Allen, Daly 2007). The involvement of fathers increases the chances of educational success of a child (Allen-Meares et al. 2010). Boys, whose fathers were more involved in care are less likely to have behavioural problems (Allen-Meares, Blazevski, Bybee, Oyserman 2010; Flourie 2008) and more likely to have pro-social behaviours (Flourie 2008; Lamb, Lewis 2010)

One could assume that the care of the father brings such positive results since we are dealing with the effect of selection (only some, the best fathers look after their children). However the studies indicate that while women spend more time on caregiving than men, currently the difference between them is much smaller than it used to be in the past (Michon 2016a; McGinnity, Russell 2008; Raley et al. 2012). In the mid-1960s, American mothers used to spend on child care four times more time than fathers, and at the turn of the century, this ratio decreased to two (Bianchi 2006). Recent research indicates that fathers are more likely to spend relatively more time caring for their children than they did historically. Additionally mothers engage in a different kind of child care tasks than fathers (Michoń 2016a; 2016b). They are more likely to be responsible for more routine and physical care than fathers. However, even in the routine tasks and physical care (feeding, bathing, changing nappies, etc.) the growth of fathers' child care involvement has been significant.

Although at the end of the twentieth century, American women still spent twice as much time doing basic tasks than their partners, considering the fact that in the sixties, this ratio was seven to one, we can consider this as a significant change (Bianchi 2006). Women's employment has contributed to increased involvement of fathers in the following aspects of physical care in particular: feeding, dressing, bathing, etc. Fathers are also more involved in the management of care. They drive their children to school or simply stay with them at home (Raley et al. 2012). Fathers whose wives work professionally, often care for their children alone (Raley et al. 2012). The increasing share of fathers in the care of the child rarely translates 
into mothers' leisure time. Studies suggest that men do not replace women in caring, they do it together or there is more care provided to the children (Hallberg, Klevmarken 2003). Parents of both genders differ also in terms of forms of spending time with children. In comparison to mothers, fathers spend relatively more time interacting with their children (playing, talking, learning) (Michoń 2016b; Bianchi 2006; Craig et al. 2010; Bianchi, Milkie 2010).

It would be wrong, however, to assume that all fathers are actively involved in the care of their children. Studies conducted in Canada indicate (Pacholok, Gauthier 2010) that at least some of the fathers do not take care of their children. The fact that distinction between caring and non-caring fathers is not determined by time constraints is interesting in this context; amount of time spent working does not determine whether fathers care for their children. Thus, according to Pacholok and Gauthier (2010), these are not the long working hours that prevent fathers from caring for children. They result in less time spent on care, however this is not the reason not to care. The differences between fathers involved and not involved in care are mainly demographic and socio-economic.

\section{Does employment reduce the time for care?}

Employment reduces the time that can be devoted to other tasks. Thus it is often assumed that paid work leads to a proportional reduction of the amount of time devoted to housework (laundry, cooking, cleaning, etc.), leisure and care. Thus if for example housework consumes $30 \%$ of women's time, it should be assumed that in case of working mothers it will be still $30 \%$ of the time left after paid work. In other words, paid work reduces the time available for other activities but the structure of the time remains the same.

Moreover, it is often assumed that child care should be included in the scope of housework, whose performance is disliked by most people. Theoretical models of the division of housework in the family are usually based on the partially justified arguments, assuming that chores are unpleasant, and as a result, each partner would prefer to avoid them. As a consequence, the partner with a lower wage, less power, and more time available should be responsible for the routine housework. Therefore, it is reasonable and then empirically confirmed that working women aim to reduce the time dedicated to housework. And since according to the theoretical models caring for children is treated simply as one of many chores, mothers' employment is expected to lead to reduced involvement in the child care-related activities.

Results of empirical studies also suggest that the amount of time spent by women on their careers only slightly affects the amount of time spent on child care. In contrast to mothers, fathers who spend more time at work spend less time caring 
for their offspring (Hallberg, Klevmarken 2003). Also, Bianchi (2000) notes that despite the increase in the female participation in the labour market the amount of time spent on child care remains relatively constant. Household duties (or at least some of them), turn out to be significantly different for working women than child care. While working women reduce, at least some housework (Michon 2015), they appear to spend with their children at least as much time as non-working mothers (Bianchi et al. 2000; Bianchi 2006; Hallberg, Klevmarken 2003). The higher parents' education level is, the time spent by them to perform household chores (other than care) significantly decreases. Inverse relationship has been observed in the case of care (Guryan et al. 2008). Why does it happen? Firstly, working women tend to devote a lot of time to their children. Hence, when the children are small they temporarily leave labour market or reduce their working time (e.g. working parttime). Secondly, the children of non-working mothers are increasingly provided with external care. Thirdly, the time during which the child is covered by various forms of non-parental care does not replace the time that parents spend caring for children. There are no significant differences in the allocation of time in families using and not using external forms of child care. Professionally active parents who would like to make time to look after their children must compromise on their rest, sleep and housework.

Investing in children, including the element of bringing them up in a family where mother is employed, leads to significant limitations in terms of time available to the family. However, female professionals usually do not reduce the amount of time devoted to their children, which is often done at the expense of their free time or by performing numerous tasks at the same time. As a result, many parents point to the difficulties in finding time for themselves and for their partner (Bianchi 2011).

It is often assumed that non-working mother devotes most of her time to child care, however this assumption also ignores some aspects. Bianchi (2000) suggests that we overestimate the amount of time non-working mothers actually devote to their children. In the past, the time the non-working mothers devoted to the active care of their children was often limited due to the need to perform household chores. In addition, in extended families, care is often provided by relatives or friends. In traditional families with clear division of roles for each partner, the woman is relatively more responsible to perform household tasks than working women. In households with two breadwinners, these differences exist but are relatively smaller. Responsibility for the provision of care often involves / is closely related with responsibility for doing housework.

It also significantly impacts the way of caring for children. Numerous studies dedicated to investments in children accept the amount of time spent on child care as an independent variable. The more time parents devote to their children the greater the level of investment and the higher opportunity costs are. If an hour of care may be more or less productive, it can produce fewer or more benefits for the child's development, i.e. investments in children can be more effective when 
a parent devotes less time, however provides high quality care (e.g. learning) than a lot of time, providing low quality care (e.g. watching TV). One of the distinctions used by researchers is a division of activities related to child care into: care performed as primary activity or care as secondary activity (Folbre, Yoon 2007). The primary care activities are characterised by high quality while the other type by lower quality. Thus if a parent cares for the child reading to him or her, or playing with the child etc., he or she provides high quality care and effectively invests in the child's development. However, if caring for children is mostly passive and done in combination with other tasks, such as cleaning, cooking, washing and performing minor repairs, the same activities represent low-quality care (Kalenkoski, Foster 2008; Bianchi 2000).

The nature of childhood is changing, so is the family model. In most developed countries families have fewer children than they used to have in the past, and the birth of the first child is usually delayed in time. Thus the decline in the number of children also reduces the total number of years during which families include small children (who require more care), which is a natural consequence of this trend. In addition, children increasingly more often are covered with organised care regardless of the status of their mothers in the labour market. Additionally, changes in the use of leisure time by their parents may also play a part. Nowadays, children can often accompany their parents in a variety of activities. The amount of time devoted to child care is also indirectly a consequence of growing concerns about children's safety child and social changes that are expressed in stressing the need to be "a good parent".

Availability of easy-to-use and effective methods of contraception means that parenting today is more voluntary, depending on the individual decision of the person, than it was in the past. Having a baby is more an expression of preferences, and hence, the parents are a selected group of adults (Sayer, Bianchi et al. 2004).

\section{Limitations}

The literature on the relationship between mothers' employment and children's cognitive and non-cognitive development contains a lot of materials that concentrate on the time devoted to child care (the amount of care), and the type of care (care as a primary or a secondary activity; educational care, routine care, physical care). Research materials document that the employment of both mothers and fathers leads to reduction of time devoted to child care, but the effect is more vivid for mothers than fathers. However, there are some non-care related explanations which may shed light on the level of investments. First of all, children face very different opportunities of success in life depending on the circumstances of their birth. Children born in relatively richer families, on average, have better achievement than 
children with a low socioeconomic status (Kalil 2015). Secondly, most of the studies on the effect of mother's employment on children's outcomes refer to the cognitive and behavioural but not to emotional outcomes. Thirdly, the studies do not take into consideration different family forms. Obviously, parents differ based on the amount of time, effort, attention or money they devote to their children. According to evolutionary explanations parents invest more in children if they are genetic parents (especially in case of men) (Apicella, Marlowe 2004) and according to the similarity-attraction phenomenon, people generally prefer others who are similar to them. The studies show that the perceived physical resemblance (Apicella, Marlowe 2004; Dolinska 2012) and personality similarity (Heijkoop et al. 2009) enable to predict parental investment in the child. For example in case of men who are no longer in the relationship with the mother of their children, resemblance appeared to be a strong predictor of investment (Apicella, Marlowe 2004). Future studies shall focus more on the consequences of family forms on parental investment. Fourthly, the amount and the effect of investment in children can be different in different countries. The differences can be rooted in the level of development of a specific country, the number of hours spent in paid work, values regarding gender roles and postmaterialistic values (Gauthier, DeGusti 2012). Fifthly, the last of the limitations is related to the nature of the social investments idea itself. One must not forget that the investment perspective does not take into consideration children's and parents' right to be cared for and to care. As human beings, children have the rights to the fundamental conditions for pursuing a good life (Liao 2015).

\section{Conclusion}

The time availability perspective rests on the assumption that individuals perform child care to the extent that they have available time, as determined by competing demands (such as paid work, child care, housework, and leisure). Thus, the time demands necessary for paid work lead to limited availability of time that can be devoted to caring. Research materials document that both mothers' and fathers' employment leads to reduction of time devoted to parental care, but the effect is more vivid for mothers than fathers. While parenting time impacts the investment in children's "quality" many observers have expressed concerns about the future generations.

The review presented in this paper suggests that although working mothers have less time available, it does not seem to influence the level of parental investment. Although the negative effect on children's cognitive development has been observed, it was mainly in case of mothers with a high level of education, mothers working full-time and during the first year after the birth of their child. In the case of children belonging to disadvantaged groups, employment of their mothers (part-time 
in particular) has led to positive implications for the development of children. Working mothers are likely to reduce the time devoted to household tasks, leisure or even sleep, to care for their children. It seems to be justified to say that in most cases, care for the child is the desired activity for both parents, especially in countries where parents do not feel a strong time pressure related to paid work. Time spent with children, especially when it is intended for recreation or education, is often indicated as one of the most pleasant activities performed during the day (especially compared to household chores). The differences between working and not working mothers with respect to child care become smaller and smaller. Nowadays children of non-working mothers are likely to participate in organised non-parental form of care (cliché, kindergarten). Both investment and consumption provide the motivation to spend time with children. As many parents care for children together, it suggests that it is an expression of common preferences (Bonke, Esping-Andersen 2011). Although it is usually mother who plays the role of main carer the role of fathers has significantly increased. Mostly fathers with a high level of education are more likely to care for their children, and so are the fathers, whose female partner works. The negative effect of mothers' employment might also be alleviated through high quality external child care arrangements. It has been shown that the external child care has positive effects on children's cognitive, language and motor skills, behaviour, school attendance, college advancement, attitudes towards education, and future wages. The argument that it is better for a child to stay at home with mother is based on the assumption that non-working mothers focus mostly on their children, however the studies show that mothers who stay at home have to perform many different tasks, and ultimately do not concentrate on their children as much as expected. From the perspective of parental investment, child care as a secondary and not primary activity, is of a lower efficiency.

\section{References}

Allen--Meares, P., Bazevski,J., Bybee, D. and Oyserman, D. (2010), "Independent effects of paternal involvement and maternal mental illness on child outcomes", Social Service Review, 84(1), pp. 103-127.

Allen S.M., Daly K.J. (2007), The effects offather involvement: An updated summary of the evidence, Centre for Families, Work \& Well-Being.

Apicella C.L., Marlowe F.W. (2004), "Perceived mate fidelity and paternal resemblance predict men's investment in children”, Evolution and Human Behavior, 25(6), pp. 371-378.

Baum II C.L. (2003), "Does early maternal employment harm child development? An analysis of the potential benefits of Leave taking", Journal of Labor Economics, 21(2), pp. 409-448.

Bernal R. (2008), "The effect of maternal employment and child care on children's cognitive development", International Economics Review, 49(4), pp. 1173-1209. 
Bianchi S.M. (2006), "Changing rhythms of family life”, [in:] Time Use and Gender Seminar, University of New South Wales (June 14), Sydney, pp. 1-16.

Bianchi S.M. (2011), "Family change and time allocation in American families", The ANNALS of the American Academy of Political and Social Science, 638(1), pp. 21-44.

Bianchi S.M., Milkie M.A., Sayer L.C., Robinson J.P. (2000), "Is anyone doing the housework? Trends in the gender division of household labor”, Social Forces, 79(1), pp. 191-228.

Bianchi S.M. (2000), "Maternal employment and time with children: Dramatic change or surprising continuity?”, Demography, 37(4), pp. 401-414.

Bianchi S.M., Milkie, M. (2010), "Work and family research in the first decade of the $21^{\text {st }}$ century", Journal of Marriage and Family, 72(3), pp. 705-725.

Bonke J., Esping-Andersen G. (2011), "Family investments in children - Productivities, preferences, and parental child care”, European Sociological Review, 27(1), pp. 43-55.

Bronte-Tinkew J., Carrano J., Horowitz A., Kinukawa A. (2008), "Involvement among resident fathers and links to infant cognitive outcomes", Journal of Family Issues, 29, pp. 1211-1244.

Brilli Y., Del Boca D. Monfardini C. (2013), "State-of-the-art report child care arrangements: determinants and consequences", Families and Societies working paper series, 2.

Brooks-Gunn J., Han W.-J. Waldfogel J. (2002), "Maternal employment and child cognitive outcomes in the first three years of life: The NICHD study of early child care”, Child Development, 73(4), pp. 1052-1072.

Campaña J.C., Gimenez-Nadal J.I., Molina J.A. (2016), "Increasing the human capital of children in Latin American countries: The role of parents' time in childcare”, The Journal of Development Studies, 0(0), pp. 1-21.

Craig L., Mullan K., Blaxland M. (2010), "Parenthood, policy and work-family time in Australia 1992-2006”. Work, Employment \& Society, 24(1), pp. 27-45.

Currie J. (2005), Welfare and Well-being of Children, Chur: Taylor \& Francis e-Library.

Dolinska B. (2012), "Resemblance and investment in children”, International Journal of Psychology, 48 (November), pp. 1-6.

Elliott S., Powell R., Brenton J. (2015), “Being a good mom: Low-income, black single mothers negotiate intensive mothering", Journal of Family Issues, 36(363), pp. 351-370.

Esping-Andersen G. (2002), “A child-centred social investment strategy”, [in:] Esping-Andersen G., Gallie D., Hemerjick A., Myles J., Why we need new welfare state, Oxford, New York: Oxford University Press, pp. 26-67.

Flouri E. (2008), “Fathering and adolescents' psychological adjustment: The role of fathers' involvement, residence, and biology status", Child: Care, Health \& Development, 34, pp. 152-161.

Flouri E., Buchanan A. (2002), “The role of father involvement in children's later mental health", Journal of Adolescence, 26, pp. 63-78.

Folbre N., Yoon J. (2007), "What is child care? Lessons from time-use surveys of major Englishspeaking countries", Review of Economics of the Household, 5(3), pp. 223-248.

Gauthier A.H., DeGusti B. (2012), “The time allocation to children by parents in Europe”, International Sociology, 27(6), pp. 827-845.

Gregg P., Washbrook E., Propper C., Burgess S. (2005), "The effects of a mother's return to work decision on child development in the UK”, The Economic Journal, 115(501), pp. F48-F80. 
Guryan J., Hurst E., Kearney M. (2008), "Parental education and parental time with children”, Journal of Economic Perspectives, 22, pp. 23-46.

Hallberg D., Klevmarken A. (2003), “Time for children: A study of parent's time allocation”, Journal of Population Economics, 16(2), pp. 205-226.

Hamilton L., Cheng S., Powell B. (2007), “Adoptive parents, adaptive parents: Evaluating the importance of biological ties for parental investment”, American Sociological Review, 72(1), pp. 95-116.

Hays S. (1996), The cultural contradictions of mother-hood, New Haven, CT: Yale University Press.

Heijkoop M., Semon Dubas J., van Aken M.A.G. (2009), "Parent-child resemblance and kin investment: Physical resemblance or personality similarity?”, European Journal of Developmental Psychology, 6(1), pp. 64-69.

Hill J.L., Waldfogel J., Brooks-Gunn J., Han W.J. (2005), "Maternal employment and child development: a fresh look using newer methods", Developmental psychology, 41(6), pp. 833-850.

Kalenkoski C.M., Foster G. (2008), “The quality of time spent with children in Australian households", Review of Economics of the Household, 6(3), pp. 243-266.

Kalil A. (2015), "Inequality begins at home: The role of parenting in the diverging destinies of rich and poor children”, [in:] Amato P.R., Booth A., McHale S.M., Van Hook J. (eds.), Diverging destinies: Families in an era of increasing inequality, Springer, pp. 63-82.

Khanam R., Nghiem S. (2016), "Family income and child cognitive and noncognitive development in Australia: Does money matter?”, Demography, 53(3), pp. 597-621.

Lamb M.E., Lewis C. (2010), “The development and significance of father-child relationships in twoparent families", [in:] Lamb M.E. (ed.), The Role of the Father in Child Development, $4^{\text {th }}$ Edition, Hoboken, NJ: Wiley, pp. 272-306.

Lee K. (2016), "Impact of child care arrangements on Australian children's cognitive outcome: Moderation effects of parental factors", Child and Family Social Work, 21(2), pp. 176-187.

Liao M.S. (2015), The Right to be Loved, Oxford, New York: Oxford University Press.

McGinnity F., Russell H. (2008), Gender inequalities in time use. The distribution of caring, housework and employment among women and men in Ireland, Dublin: The Equality Authority and The Economic and Social Research Institute, Available at: www.equality.ie/research (last accessed 04.05.2018).

Michoń P. (2014a), “Dzieciństwo w Bullerbyn czy z tiger mothers? Bycie dzieckiem a stawanie się szczęśliwym dorosłym - zastrzeżenia wobec stosowania perspektywy inwestycji społecznych w polityce społecznej”, Przegląd Socjologiczny, 63(4), pp. 93-106.

Michoń P. (2014b), “ "Nie rozdwoję się przecież. Konflikt czasu jako przeszkoda w osiąganiu równowagi pomiędzy pracą a życiem prywatnym w Polsce”, [in:] Tomaszewska-Lipiec R. (ed.), Relacje praca - życie zawodowe droga do zrównoważonego rozwoju jednostki. Bydgoszcz: Wydawnictwo Uniwersytetu Kazimierza Wielkiego, pp. 94-112.

Michoń P. (2016a), “Udział ojców w czynnościach związanych z opieką nad dzieckiem - międzynarodowa analiza porównawcza”, Prace Naukowe Uniwersytetu Ekonomicznego we Wrocławiu, (438), pp. 64-80.

Michoń P. (2016b), “Zabawa czy rutyna? Podział czynności związanych z opieką nad dzieckiem pomiędzy kobietę i mężczyznę w gospodarstwach domowych w Polsce”, Studia Oeconomica Posnaniensia, 4(9), pp. 55-73.

Michoń P. (2015), “Zatrzymana rewolucja? Zmiany w podziale pracy w gospodarstwach domowych. Międzynarodowe badanie porównawcze", Poliytka Społeczna, (2), pp. 27-33. 
Pacholok S., Gauthier A. (2010), "Non-participant fathers in time-use studies: Uninvolved or data artifact?”, Social Indicators Research, 96(2), pp. 249-266.

Raley S., Bianchi S.M., Wang W. (2012), “When do fathers care? Mothers' economic contribution and fathers' involvement in child care", American Journal of Sociology, 117(5), pp. 1422-1459.

Ruhm C.J. (2008), “Maternal employment and adolescent development”, Labour Economics, 15(5), pp. 958-983.

Sayer L.C., Gauthier A.H., Furstenberg F.F. (2004), “Educational differences in parents' time with children: Cross-national variations", Journal of Marriage and Family, 66(5), pp. 1152-1169. 